\title{
Integrated Drilling Optimization A Success Story in the Basin of North Africa
}

\author{
Aly Rasyid \\ Petroleum Engineering Department, University of Bhayangkara Jakarta Raya \\ aly.rasyid@dsn.ubharajaya.ac.id
}

\begin{abstract}
Drilling optimization objective was to reduce costs, improve wellbore conditions and integrity for increasingly challenging reservoirs while establishing maximum safety performance and environmental custodianship. Even though the final result of a drilling operation is easily observed, what almost always goes unnoticed is the complexity of the issues involved in the planning and execution of a drilling operation and the number of topics involved in such a process.
\end{abstract}

In this paper, as case study of the exploration drilling in Hamada region, North Africa has been evaluated. Over the period of 2006 to 2011, continued drilling improvement was achieved. Key elements in the optimization included focus on management drilling team structure, engineering well planning, improvements on managing drilling operations such as on site safety management practices, and also post drill analysis to implement lesson learn for the next well to be drilled.

As the result, while drilling 26 wells during the 2006 until 2011, drilling days were successfully reduced from 87 days (first well) to the average 40 days, and very good safety record.

Keywords: optimization, drilling cost, drilling performance

\section{INTRODUCTION}

The basin in this paper is located about $200 \mathrm{~km}$ to the south west of Tripoli. All of area is desert environment at about 2,000 ft above sea level. The nearest community is located about $50-100 \mathrm{~km}$. This challenging environment had to be face for exploration drilling campaign.

The main objective of this paper is to describe how drilling team managed the integrated drilling optimization (IDO) workflow for all of aspects drilling activity starting from well planning, set up drilling team, tendering and procurement process, hiring company services, managing drilling operations, and post well review for lesson learnt. The process is widely divided into main phases: planning, managing operations and post analysis see figure-1.

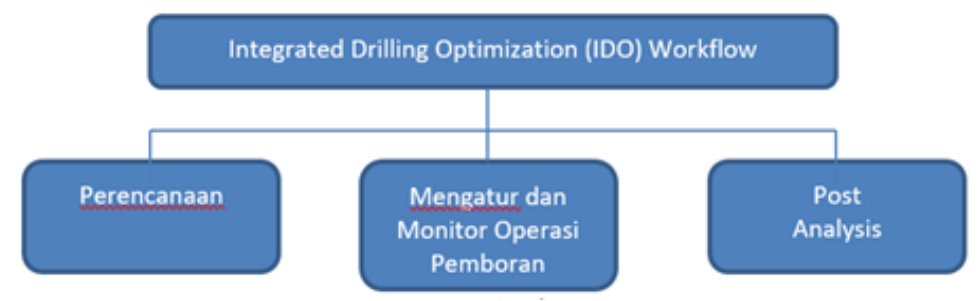

Figure 1. Drilling optimization workflow

\section{METHOD}

The method to describe this case study by narrative descriptive based on actual experiences in the field. Starting from Planning, purchasing and tendering process, developing and building manpower, during execution of the drilling program such as managing operations, handling the local people, transportation, water supply, as well as close out program for the continues improvement of the drilling results.

\section{WELL PLANING}

During well planning, there are several key activity that need to be accomplished which are: establish objective, gather data, identify offset well, risk register and mitigation plan and define drilling and completion program. 
The objective of drilling is very clear that drilling operations has to be drill the well not only as quick as possible but also establishing maximum safety in order to provide best access to the target oil reservoir.

Five offset wells were identified to gather all of necessary data to drill the first well in Area. The complete set data from the final well report of the offset well such as well profile, drilling fluid design, pressure data, well testing data, casing seating, general well problem, casing and cementing design, also drilling time/days as well as well cost. The summary of offset well data performance can be seen in the table- 1 .

Table 1. Offset Well Data Performance

\begin{tabular}{|c|c|c|c|c|c|}
\hline \multirow{2}{*}{ Sumur } & \multirow{2}{*}{ Tahun } & \multirow{2}{*}{ TD - ft } & \multirow{2}{*}{ CASING } & \multicolumn{2}{|c|}{ Hari Pemboran } \\
\hline & & & & To TD & To RR \\
\hline $\mathrm{XA}$ & 1998 & 11400 & $\begin{array}{l}\text { 13-3/8"” @ 3700' } \\
\text { 9-5/8" @ } 8800^{\prime} \\
7^{\prime \prime} @ 8500^{\prime} \text { to } \\
\text { 11400' }\end{array}$ & 110 & 135 \\
\hline $\mathrm{XB}$ & 2000 & 10800 & $\begin{array}{l}\text { 13-3/8"@ @ 1200' } \\
\text { 9-5/8" @ 8100' } \\
\text { 7"@ 10800' }\end{array}$ & 115 & 155 \\
\hline $\mathrm{XC}$ & 1992 & 11786 & $\begin{array}{l}\text { 20"@612' } \\
\text { 13-3/8" @3970' } \\
\text { 9-5/8"@8535' }\end{array}$ & 90 & 110 \\
\hline $\mathrm{XD}$ & N/A & $\sim 11800$ & & 90 & 110 \\
\hline $\mathrm{XE}$ & 1993 & 10320 & $\begin{array}{l}\text { 13-3/8"@780' } \\
\text { 9-5/8"@4067' } \\
\text { 7"@10310' }\end{array}$ & 65 & 95 \\
\hline
\end{tabular}

The main drilling hazards from the offset well were reflected in the drilling program as follow:

1. 20" conductor section: Total lost circulation was encountered in the offset well. Have LCM ready all time.

2. 17-1/2" section: Full Lost circulation is expected. Ensure an adequate supply of LCM is available. XG1$\mathrm{XN} 2$ and water well had full losses during the drilling and cement job. They pumped cement plugs to cure lost circulation a few times.

3. 12-1/4" section: Tight hole problem was occurring throughout drilling process. Minor reaming and cleaning are expected on most trips.

4. 8-1/2" section: Offsets indicate the following potential problems: sever gauge wear, loss circulation in Memouniat, and possible $\mathrm{H}_{2} \mathrm{~S}$ in Memouniat.

\section{DRILLING TEAM SETUP}

Unlike larger companies, the drilling team was setup as a small group with positions taking on multi tasks. This small team of experts handled all the drilling and completions operations. The organization structure of the drilling team is shown in Figure-2. There were several key persons that have main function as follow:

1. Operations manager : head of drilling and completion activity

2. Drilling and completion superintendent: manage the whole operations for drilling and completion activity, daily in touch with field adviser and company man in the field.

3. Drilling and completion engineer: handle well engineering planning, AFE preparation, reporting and post engineering analysis.

4. Drilling and completion field adviser: coordinate field activity including lease construction, operate and maintain water well, monitor rig personal safety performance, coordinate with company man to ensure smooth operations.

5. Drilling company man: responsible for all of the rig drilling activity, ensure drilling operations go ahead as planned, make decisions affecting progress of the well, and organize supplies of equipment.

6. Well completion company man: responsible for all of the completion rig activity, ensure completion operations go ahead as planned, make decisions affecting progress of the well, and organize supplies of equipment.

7. Material coordinator: keep material required for the operations is ready to use and manage all of material transfer from port to the material warehouse in the field, also from warehouse to the well.

8. Purchasing \& procurement coordinator: manage all of contract's services and purchase the material that requires for the drilling and completion operations.

Rotation base, 28 days working and 28 days off was implemented for all of drilling team. This rotation base working was successfully help the personnel to get refresh after 28 days fully working especially for field personnel. The Drilling \& Completions Superintendent and Purchasing \& Procurement positions were resident in Tripoli, all other positions were rotational. The entire operations team was initially all Expatriates with the Drilling and Completions Superintendent having previous history in Libya of 6 years others operators. 


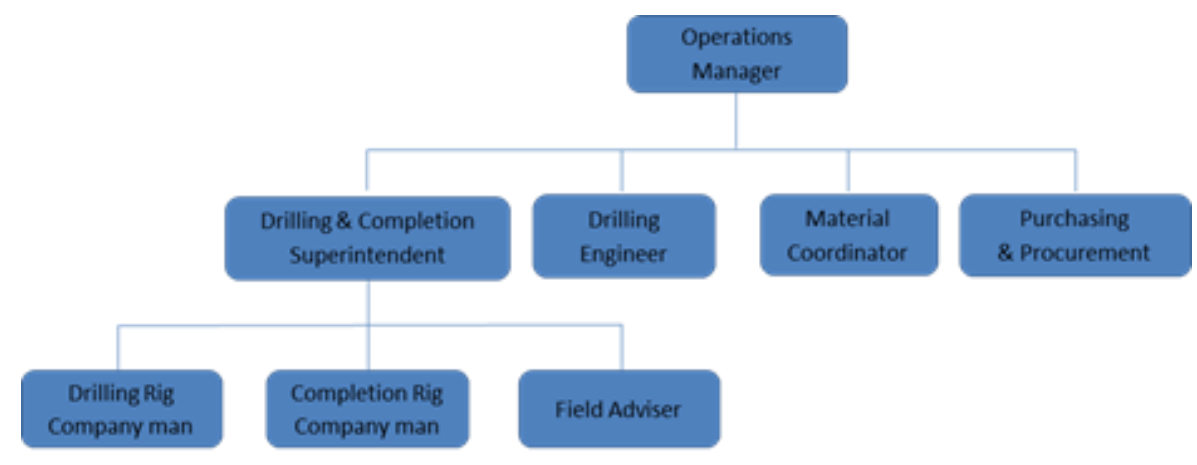

Figure 2. Drilling Team Organization Structure

\section{PROCESS TENDER / PROCUREMENT}

Tendering and procurement coordinator was responsible to prepare all necessary document for all of hiring services and material required for the operations including casing, tubing, wellhead, other material and down hole tools.

The strategy of drilling contract is day-rate contract. The advantage for this contracting strategy that as an operator has fully control for the whole services, design, and planned operations. In the case of the day-rate contract the operator prepares a detailed well design and program of work for the drilling operation and the drilling contractor simply provides the drilling rig and personnel to drill the well. The contractor is paid a fixed sum of money for every day that he spends drilling the well.

QA/QC for Selection of drilling services/contractors is one of essential key for successful drilling operations. Technical and commercial evaluation for all services were done objectively, so that the result from this selection process was services or contractors that already has good experience, good material specification, good man power, and good performance as well. The technical \& commercial evaluation sheet has been developed to determine recommended contractor.

Throughout the contract period contract rates were continually discussed and re-negotiated in a downward trend. As well and emphasis was placed on additional contract discounts, a move initiated by NOC's Chairman of the Management Committee which resulted in an overall discount of $25 \%$ in costs.

Discussions to improve contractor's services was also discussed and the relationships between contractor - operator 3rd parties were unique and all suggestions for improvements were taken seriously and implemented when cost and benefit was observed.

\section{MANAGING DRILLING OPERATIONS}

Managing drilling operations basically is to implement the best practices in drilling engineering and operations itself. In Area of Basin, beside it has done the best practices, some strategy to have the drilling operations more smooth was performed in order to overcome any difficulties.

There are two major issues which impact drilling operations performance in desert environment, the first is water availability and the second is transportation. For these two kinds of issue, the drilling team has prepared with the action in more advance in the front.

Beside water availability and transportation, another issue like personal in-charge, improvement in the rig equipment and safety management practices could be highlight in the following paragraph.

\section{Water availability}

Before we drilled the first oil well, we had drilled water well. So that, water well was ready before start drilling oil well. Utilize the drilling/workover rig to drill the water well was more efficient in term of timing as well as cost. Target depth for water well was from Chicla sandstones between 2000 and $3000 \mathrm{ft}$, that was believed to be a renewable resource and provided good deliverability. A total of 4 water wells were drilled in Area of the Basin to service all the drilling and testing/completions operations. From the water wells, water was distributed by 3 inch plastic line and supplemented by local water trucks. Large water reserve pits of $8-10,000$ bbls were constructed at each of the location. The water trucks were contracted from local companies.

With only drilling 4 water wells compared to other operators drilling a water well for each location, considerable savings with respect to water was achieved for the overall campaign. 


\section{Transportation}

Sometimes, it was very difficult to have trucking company, or event we have contract with trucking company, it was not easy to get our materials like casing, tubing, wellhead etc., standby in the site. The solution to this problem was to build $\mathrm{X} 1$-yard that located in the center of Area of the Basin. All of materials that required for the next drilling well were standby at X1-Yard, so that it was easier to get materials mobilized and ready in the well site. Another advantage that was we did not pay any rent cost for warehouse.

\section{Selective personal in-charge}

Key person in the rig who has very influence to the operations, like company man and driller was selected by company. They were not from rig contractors, but selected based on experience and competency required. It was proven, that hiring direct contract for driller made drilling operations more efficient rather than using driller that provided by rig contractor.

\section{Improvement on the rig equipment}

Some of part of rig equipment has been used for long of period, so that need to be refurbished or need additional equipment. While drilling the well, we could see out of performance of mud pump, top drive system, rig engine, etc for example, that perhaps this was missed during rig acceptance test. Therefore, the drilling team should notify if there was any equipment that poor performance or need to be rectified/replaced. An example additional equipment that has been hired to make better performance on drilling fluid is centrifuge equipment.

\section{Safety management practices}

Safety Procedures and Emergency Respond Procedure was established prior to start the drilling operations. Safety meeting was performed before spud the well, so that everybody would know who do what and their responsibility according to drilling or completion program.

Awareness to follow safety procedures and best practices is a must for all of personnel in the rig site. Company man and field safety adviser has responsibility to ensure all of personnel were equipped with personnel safety equipment like helmet, hand glove, goggle, and safety boot. Safety training especially for well control certification was done regularly every 2 years for certain personnel.

\section{Rig strategy}

From the beginning of the campaign the decision was made to utilize one drilling rig and one service rig. Upon discovery which happened to be the first well, the decision was made to employ a second rig, this strategy freed up the drilling rigs from well testing operations leaving this operation to a more easily mobile rig at a much cheaper day rate, while the drilling rigs could move and drill as many wells as possible so as to explore the whole of the block or explore as much of the potential of the block within the exploration period. Also having a second rig, this would keep on rig busy with exploration and the second rig busy with appraisal wells. This strategy is not often practiced in Libya especially in exploration. This "risk decision" paid off in the long run saving considerable amount of time and funds.

\section{Rig supervision}

From the beginning it was decided to man each of the rigs with 24 hours supervision. The decision was to man the rigs with Western personnel and bring on local staff as appointed. During the campaign and total of 4 engineers were assigned and after receiving some training in Tripoli, they started field training, with one of the engineers being appointed as a Night Drilling Supervisor. Constant 24 hours supervision is very important and this contributed in a large part to our success. Not all but some of the supervisors came to this Area with previous Libyan experience, but all of the supervisors came with previous international experience.

\section{POST ANALISIS}

After finished drilling a well, there was evaluation to identify main problem and making any solution or recommendation in order to have better design or planning for the next well. This is called post analysis. This analysis is not only limited to engineering design, but also for the whole operations.

Several changes in the well design and results can be written down below here:

1. Fluid design was changed due to caving problem. Result: couple of last wells was indicated no caving problems any more.

2. Type and model of down hole motor was changed several times, as trial and error, and finally find the best combination between drill sting, drill collar, stabilizer, motors, mud pump capacity, and top drive capability. Result: drilling much faster.

3. Casing seating has changed due to lost circulation and tight hole issues. Result: drilling much faster. 
4. Utilizing PDC bit for 12-1/4" and 8-1/2" section. For PDC bit, we invited four different services to provide their PDC bit as consignment and give them chance to provide their services equally, then let they made bit evaluation and recommendation since every year there were new bit technology coming. Result: NOC recognition for bit record. As well all the bit companies in Libya have a great understanding of Basin and types of PDC bits which work the best. This not just helped, but helped the overall understanding and in general will help all operators establish peak performance when drilling the Basin.

5. Light-create cement utilization for $95 / 8$ " and 7 " liner cementing. Result: better good cement bonding performance in this section.

\section{OPTIMIZATION RESULT}

Having a good planning, managing the whole operations with the best practices, and finally performing post analysis was done successfully by the drilling team. The result was still not perfect, but there was a dramatic decrease in drilling days as well as total cost. In the other hand, from the testing result was proved good deliverability of oil and gas, and the average skin factor was considerably very small that means hole condition was not damaged or good access for upcoming production stage. A low skin damage can best be described as good drilling practices which the drilling supervisors played a very active role.

From safety point of view, we noticed that start from the beginning in 2006 until 2011, there was no recordable accident and zero LTI (lost time injury), that means very good safety record.

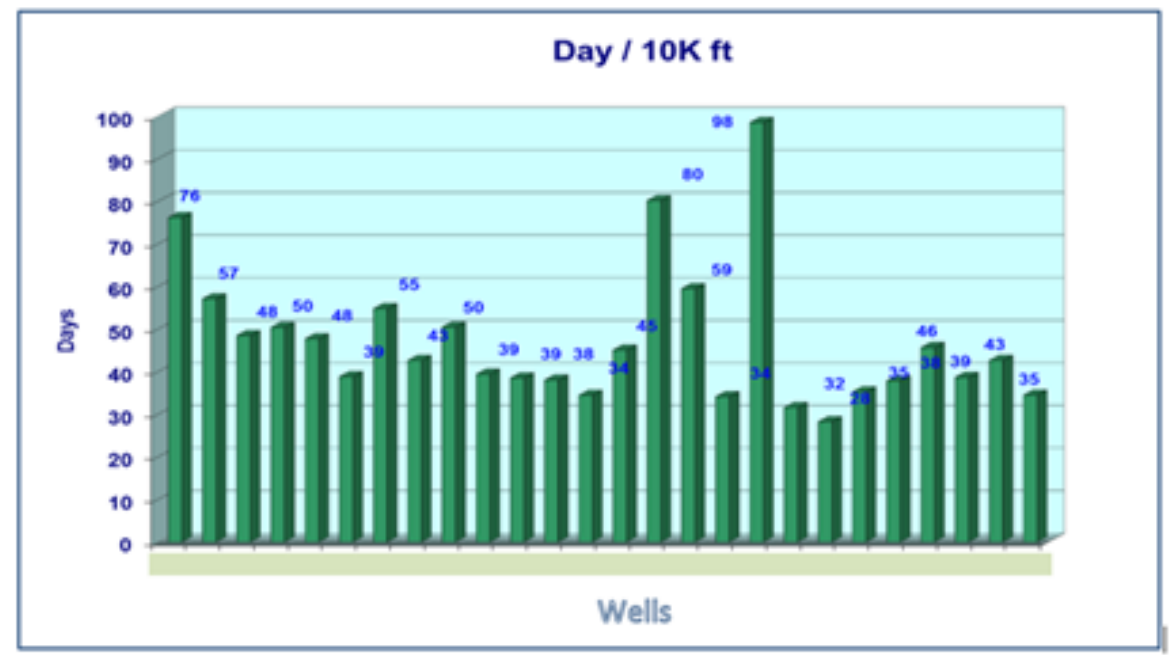

Figure 3. Drilling Days / 10,000 ft

\section{CONCLUSION}

1. Integrated drilling optimization was done successfully by the drilling team in the Area of the Basin.

2. Drilling optimization was contained but not limited to well planning, tendering and procurement process, setup drilling team, managing drilling operations, and post analysis.

3. The result of integrated drilling optimization is a significant decrease on the drilling days and cost of the well with good well deliverability and good safety record.

\section{REFERENCES}

A.L Martins, A.F.L Aragao, P.E Aranha, M.G Folsta and A.T.A Waldmann. 2011. Well Construction Hydraulics in Challenging Environments, SPE 140145, March 2011.

Arve K. Thorsen, Elin Vargervik, Vebjorn Nygaard. 2009. Combining Drilling Evaluation Technology in Remote Operations Increases Reliability, SPE 124729.

J.M Aldawood, K Ahmad, Y.S Al-Ansari, B.A Zubairi, M.X Hanafi. 2011. Integrated Pre-Well Planning Process Improves Service Quality and Decreases Risk through Cooperation between Drilling and Geosciences, SPE 140023. 
S.M Boutalbi, D.A Pavel, M.B Grayson. 2011. Can Safety Improvement Increase Drilling Efficiency?, SPE 139995, March 2011.

Steve Vogel, Jamel Asker. 2010. Real Time Data Management and Information Transfer as and Effective Drilling Technique, IADC/SPE 136296, November 2010. 